\title{
Palynodebris analysis of a shallow core from the Barents Sea
}

\author{
TORBJØRN THRONDSEN AND TOR BJARKE
}

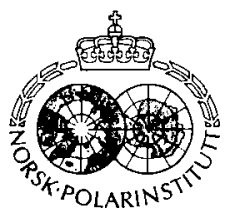

Throndsen, T. \& Bjærke, T. 1983: Palynodebris analysis of a shallow core from the Barents Sea. Polar Research 1 n.s., 43-47. Oslo.

A quantitative study of palynomorphs and palynodebris in a shallow core from the central part of Bjørnøyrenna, western Barents Sea, is presented. The core could be subdivided into a lower part characterized by a complete dominance of reworked plant debris of Mesozoic age and an upper part with considerable input of first cycle algal debris and dinoflagellate cysts. Two hypotheses are suggested to explain this radical change in palynodebris composition. Either it represents a transition from a situation with permanent ice to normal marine conditions, or the absence of first cycle plant debris in the lower part of the core is caused by a masking of this component due to extremely high input of glacially eroded material from the bordering shallow parts of the Barents Sea. The present study shows that palynodebris analysis may contribute important information to the study of composition and depositional environment of Quaternary marine sediments in the area.

Torbjørn Throndsen, Saga Petroleum a.s., P.O. Box 9, 1322 Høvik, Norway; Tor Bjarke, LAP, PB118, 3290 Stavern, Norway. March 1982 (revised January 1983).

\section{Introduction}

During the 1970s Norsk Polarinstitutt and Oljedirektoratet carried out extensive sampling of unconsolidated sediments from the Barents Sea. Gravity cores from the deeper parts of Bjørnøyrenna penetrated two characteristic lithological units in the upper 2 to $3 \mathrm{~m}$ of the bottom sediment: an upper fine-grained, olive-grey soft mud 20 to $100 \mathrm{~cm}$ thick and a lower blue-grey mud. Dropstones are present in both units, but most common in the lower unit. Detailed sedimentological and micropalaeontological studies have been carried out on this material during recent years (see Elverhøi \& Solheim 1983). In order to test the potential of palynodebris analysis and palynology for interpretation of the sedimentation history in this type of environment, a detailed study was carried out on one of these cores. (Palynodebris is defined as the total solid organic matter remaining after $\mathrm{HCl}$ - and $\mathrm{HF}$ treatment of a sediment sample; this definition extends the use of the term compared with that applied by Manum 1976.)

The core selected for study is located in the eastern part of Bjørnøyrenna at a water depth of $400 \mathrm{~m}$. The core reached $1.9 \mathrm{~m}$ and was sampled every $10 \mathrm{~cm}$ (Fig. 1). By removing the outer surface before sampling, care was taken to avoid contamination from other parts of the core.
Standard palynological preparation techniques were applied. Both total palynodebris (unscreened) and screened residues ( 20 micron net) were studied in strew mounts.

\section{Palynology}

Palynomorphs were grouped into three different categories: dinocysts, bisaccate pollen, spores, and pollen other than bisaccates. Based on preservation and colouration, each of these categories could easily be separated into first cycle and reworked palynomorphs. In addition acid resistant inner linings of foraminifera were recorded, probably of first cycle origin. The relative amount of each of the categories was obtained by counting 200 to 300 specimens from each sample in screened residues. The results are shown in Fig. 2.

Below $1.00 \mathrm{~m}$ nearly all palynomorphs are reworked from older sediments; only a few first cycle dinocysts were recorded from this interval. Spores and pollen $\left(S_{1}\right)$ account for 60 to $80 \%$, while bisaccates $\left(B_{1}\right)$ and dinocysts $\left(D_{1}\right)$ each make up 10 to $20 \%$ of the total assemblage.

At $0.85 \mathrm{~m}$ first cycle bisaccates $\left(B_{2}\right)$, spores and pollen $\left(\mathrm{S}_{2}\right)$, and foraminifera $(\mathrm{F})$ make their first appearance. Foraminifera make up about $10 \%$ of the total assemblage, and first cycle bisaccates 


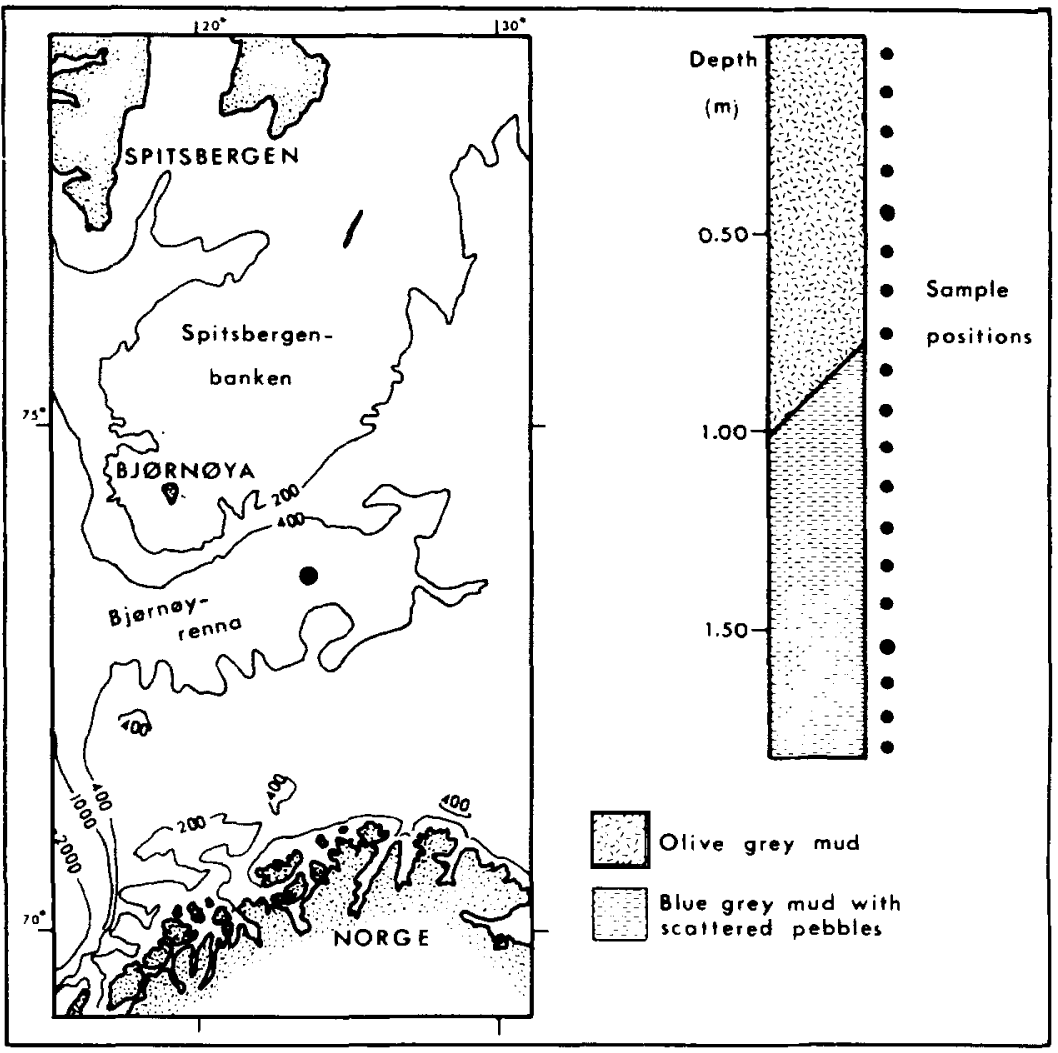

Fig. 1. Location and lithology of studied core (BGR 16-77-18).

and spores and pollen $5 \%$ or less throughout the upper part of the core.

Between 0.65 and $0.45 \mathrm{~m}$ a rapid change in assemblage composition takes place by an increase in first cycle dinocysts $\left(D_{2}\right)$. At $0.45 \mathrm{~m}$ they make up more than $50 \%$ of the total assemblage and above this level vary between 50 and $70 \%$. In this part of the core, reworked spores and pollen $\left(S_{1}\right)$ are reduced to 10 to $30 \%$, while reworked bisaccates $\left(B_{1}\right)$ and dinocysts $\left(D_{1}\right)$ each make up $10 \%$ or less of the total assemblage.

Among the reworked palynomorphs a few dinocysts could be identified. The presence of Cribroperidinium sp., Odontochitina sp., Cyclonephelium eisenackii, Pseudoceratium cf. regium, Cyclonephelium distinctum, cf. Paleoperidinium cretaceum, Deflandrea sp. and spores of the Cicatricorisporites-type show that Cretaceous sediments are the main source. A few specimens of Upper Triassic palynomorphs belonging to Kyrtomisporis speciosus, Zebrasporites interscriptus and cf. Protodiploxypinus sp. were also observed. They are characteristic of the Upper
Triassic part of the Wilhelmøya Formation now exposed on Hopen and probably on Spitsbergenbanken just west of Hopen (Bjærke 1979).

The dominance of first cycle dinocysts in the upper $0.50 \mathrm{~m}$ of the core is due to a single species, Operculodinium centrocarpum. Rare specimens of the genera Spiniferites and Nematosphaeropsis were also observed. First cycle pollen are rare, only a few specimens belonging to Betula and Pinus were observed.

\section{Palynodebris}

When dealing with palynodebris comprising variably degraded and corroded fragments due to heterogeneous origin, four categories are usually distinguished in transmitted light. Bujak et al. (1977) defined the four groups as:

Amorphogen: unorganized, structureless organic debris which may be finely disseminated or cohering into fluffy masses. 
Fig. 2. Palynomorph distribution in core (BGR 1677-18).

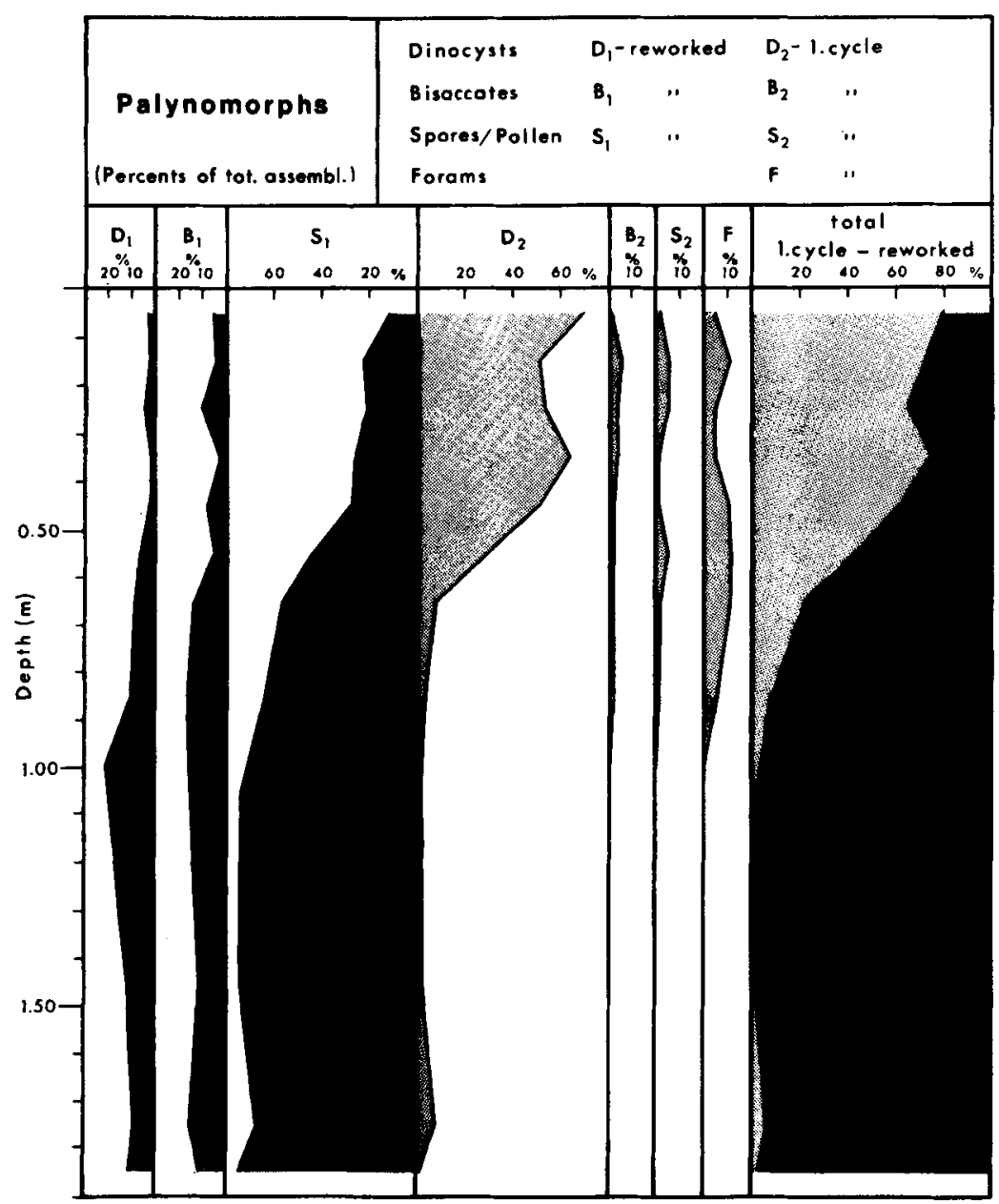

Phyrogen: all non-opaque, recognizable plant matter that is not of wood origin including plant cuticles, palynomorphs, resin bodies and acid resistant inner linings of foraminifera. Also translucent particles fragmented or degraded beyond identification are included. In the present study first cycle $\left(\mathrm{P}_{2}\right)$ and reworked $\left(\mathrm{P}_{1}\right)$ phyrogen are distinguished on the basis of colouration. First cycle phyrogen has a freshly green to pale yellow colour, while reworked phyrogen is deep yellow or brown.

Hylogen: translucent fragments of woody origin. Fragments with a red-orange translucency along margins or other thinned areas but otherwise opaque are also included.

Melanogen: opaque organic matter typically com- prising angular, fissured fragments, sometimes with cellular structures.

The quantity of amorphogen relative to the other palynodebris components was visually estimated from strew mounts of the total assemblage (unsieved residue). The relative amounts of the other particulate palynodebris categories were obtained from counts of 150 to 400 fragments in strew mounts of screened residues. The results are shown in Fig. 3.

Amorphogen (A) dominates in all samples. Both finely disseminated and coherent amorphogen is present throughout, but coherent masses are more common in the upper part of the core. The dominance of amorphogen suggests sedimentation in a low energy environment (Bujak et al. 1977; Manum \& Throndsen 1978). 


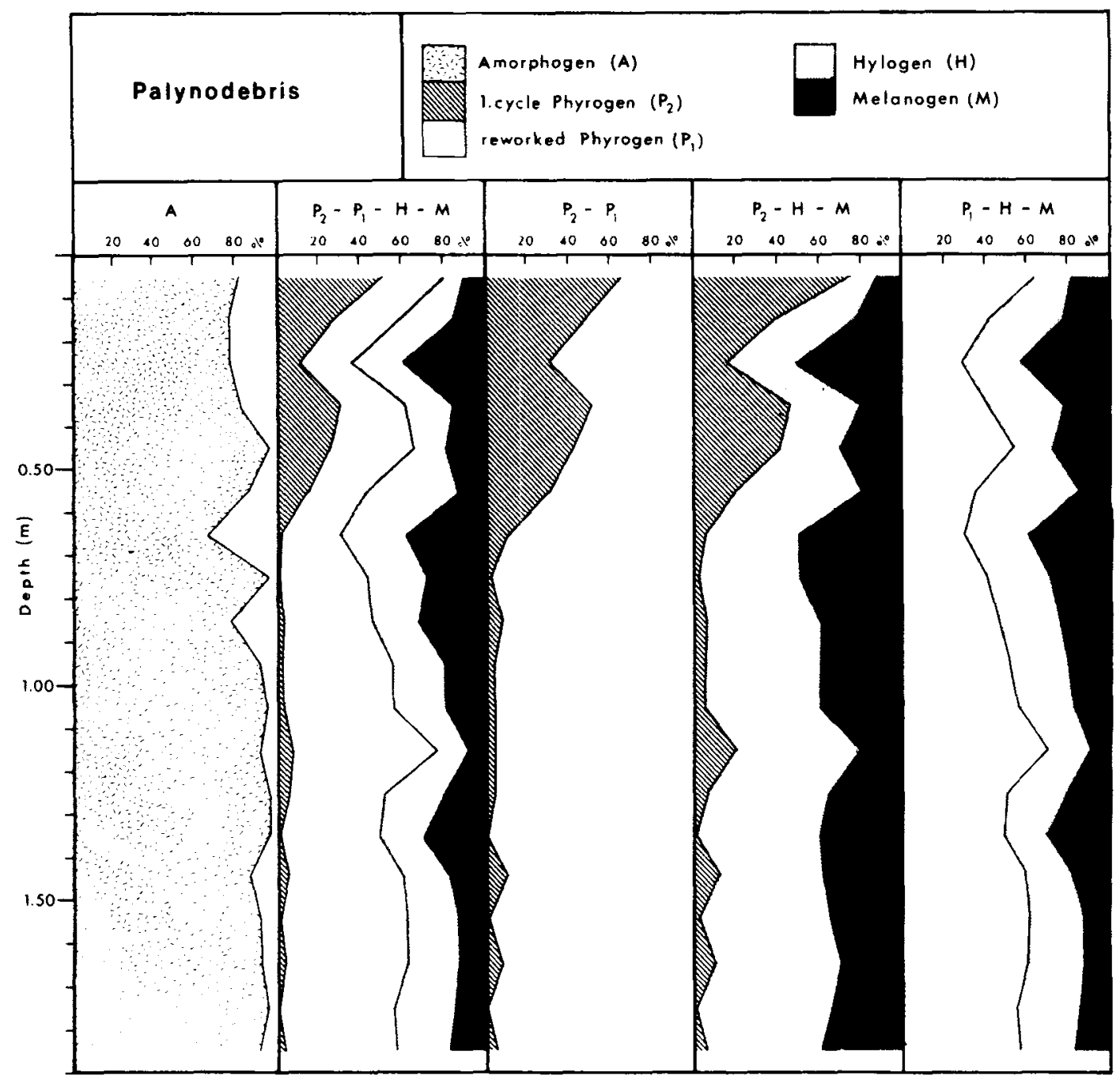

Fig. 3. Palynodebris distribution in core (BGR 16-77-18).

Phyrogen makes up slightly more than $50 \%$ of the particulate palynodebris (amorphogen excluded). Below $0.65 \mathrm{~m}$ there is a strong and consistent dominance of reworked phyrogen $(P)$. From $0.55 \mathrm{~m}$ upwards there is an increased input of first cycle phyrogen $\left(\mathrm{P}_{2}\right)$. This is mainly due to an increase in marine dinocysts. First cycle phyrogen of terrestrial origin is rare, and first cycle cuticles are absent. A similar trend is also seen when comparing the relative abundance of first cycle phyrogen $\left(\mathrm{P}_{2}\right)$ with hylogen $(\mathrm{H})$ and melanogen $(\mathrm{M})$. On the other hand, reworked phyrogen $\left(\mathrm{P}_{1}\right)$ relative to hylogen and melanogen does not show this trend. This indicates that there was no deposition of first cycle plant material of terrestrial origin except for rare pollen and spores.

\section{Conclusions}

In the core studied here amorphogen dominates throughout showing that deposition took place in a low energy environment. Only traces of first cycle terrestrially derived material have been recorded. This means that there has been no input of sediment material from a land area covered by vegetation. The most likely sediment source is Mesozoic rocks being eroded in more shallow 
parts of the Barents Sea. The reworked palynomorphs identified in the material show that the eroded sediments are mainly of Cretaceous age. The input of reworked plant debris is considerable throughout. A comparison with the results of a regional study of rock fragments from the Barents Sea makes a northern to northeastern source area most likely (cp. Bjærke 1979). Bjørlykke et al. (1978) discussed the mineralogical and geochemical composition of Quaternary clays from the Barents Sea and concluded that it was controlled by reworking of Mesozoic sediments. This observation is supported by our results.

The subdivision of the core section into two units, an upper olive grey and a lower blue-grey mud, is clearly related to the palynomorph and palynodebris assemblages. In the lower unit, below $1.00 \mathrm{~m}$, reworked palynomorphs make up nearly $100 \%$ of the total assemblage, and reworked phyrogen shows a strong dominance over first cycle phyrogen. This lack of first cycle plant debris and palynomorphs in the lower unit may be explained either by a permanent cover of floating ice during deposition or by an extensive masking of the first cycle material due to extremely high input of fine grained reworked material from glacially eroded areas. In the upper unit, above 1.00 , there is a rapidly increasing input of first cycle plant debris mainly due to marine dinocysts and amorphous algal debris resulting in the olive-grey colour of this part of the core section. This abundance of dinocysts and algal debris shows that open, normal marine conditions were established during the deposition of this unit.

Acknowledgements. - We thank Anders Elverhøi for making the material available and for providing information regarding sampling and lithostratigraphy, and Barrie Dale for helpful discussions and identification of Quaternary dinocysts. Financial support from the Norwegian Council for Scientific and Industrial Research (NTNF) is acknowledged.

\section{References}

Bjærke, T. 1979: Geology of the Barents Sea shelf; Evidence from palynological studies of drift material. Norwegian Sea Symposium (NSS) 17-1-15. Norwegian Petroleum Soc. 1979.

Bjørlykke, K., Bue, B. \& Elverhøi, A. 1978: Quaternary sediments in the northwestern part of the Barents Sea and their relation to the underlying Mesozoic bedrock. Sedimentology 25(2), 227-246.

Bujak, J. P., Baras, M. S. \& Williams, G. L. 1977: Offshore East Canadas organic type and color and hydrocarbon potential. Part I Oil and Gas J. 75(14), 198-202; Part II Ibid 75(15), 96-100.

Elverhøi, A. \& Solheim, A. 1983: The Barents Sea ice sheet - a sedimentological discussion. Polar Research 1 n.s., (this volume).

Manum, S. B. 1976: Dinocysts in Tertiary Norwegian-Greenland Sea sediments (Deep Sea Drilling Project Leg 38), with observations on palynomorphs and palynodebris in relation to environment. Pp. 897-919 in Talwani, M., Udintsew, G. et al. Initial Reports of the Deep Sea Drilling Project XXXVIII: 29. (chapter 29).

Manum, S. B. \& Throndsen, T. 1978: Dispersed organic matter (kerogen) in the Spitsbergen Tertiary. Norsk. Polarinst. Arbok 1977, 179-187. 
